\title{
Endogenous Neurotrophin-3 Regulates Short-Term Plasticity at Lateral Perforant Path-Granule Cell Synapses
}

\author{
Merab Kokaia, ${ }^{1}$ Fredrik Asztely, ${ }^{1}$ Klara Olofsdotter, ${ }^{1}$ Carlos Balet Sindreu, ${ }^{1}$ Dimitri M. Kullmann, ${ }^{2}$ and \\ Olle Lindvall ${ }^{1}$ \\ 1Section of Restorative Neurology, Wallenberg Neuroscience Center, University Hospital, S-221 85 Lund, Sweden, and \\ 2Department of Clinical Neurology, Institute of Neurology, Queen Square, London WC1N 3BG, United Kingdom
}

In the adult brain, neurotrophin-3 (NT-3) is mainly localized in dentate granule cells, and its expression is decreased by various stimuli, e.g., seizure activity. We have examined the role of endogenous NT-3 for excitatory synaptic transmission at lateral perforant path-dentate granule cell synapses using hippocampal slices from NT-3 knock-out (+/-) and wild-type $(+/+)$ mice. Paired-pulse facilitation (PPF) and also short-term synaptic plasticity induced by a brief, high-frequency train of afferent stimulation were reduced, but the expression of long-term potentiation was not affected in the NT-3+/- mice. Incubation of the slices with recombinant NT-3 reversed the deficit in PPF through a mechanism requiring de novo protein synthesis,

The neurotrophins, nerve growth factor (NGF), brain-derived neurotrophic factor (BDNF), neurotrophin-3 (NT-3), and neurotrophin $4 / 5$ regulate neuronal survival and differentiation during embryonic development and maintain the structure and function of specific neural systems in the adult brain (Lindsay et al., 1994; Lewin and Barde, 1996). Recent experimental evidence indicates that neurotrophins can have acute effects on synaptic transmission and that these factors may be involved in the regulation of neuronal plasticity in both the developing and mature CNS (Kim et al., 1994; Lessmann et al., 1994; Kang and Schuman, 1995; Levine et al., 1995; Thoenen, 1995; Bonhoeffer, 1996; Lu and Figurov, 1997). Several observations imply that endogenous BDNF can play a role in long-term potentiation (LTP), a model of synaptic plasticity believed to be a cellular correlate of certain forms of learning and memory (Bliss and Collingridge, 1993). Mice with a targeted disruption of the BDNF gene show impairment of hippocampal LTP at the Schaffer collateral-CA1 synapse, and this deficit can be reversed by exogenous BDNF (Korte et al., 1995, 1996; Patterson et al., 1996). In agreement with this, antibodies to the high-affinity BDNF receptor TrkB and TrkB$\mathrm{IgG}$ fusion proteins that bind and inhibit endogenous BDNF interfere with the induction and maintenance of LTP in hippocampus (Figurov et al., 1996; Kang et al., 1997) and developing visual cortex (Akaneya et al., 1997).

Received June 1, 1998; revised Aug. 19, 1998; accepted Aug. 20, 1998.

This work was supported by the Swedish Medical Research Council, Knut and Alice Wallenberg Foundation, Thorsten and Elsa Segerfalk Foundation, Crafoord Foundation, Kock Foundation, and Royal Physiographic Society. K.O. was supported by the Swedish National Network in Neuroscience. We thank Monica Lundahl for technical assistance and Marie Lundin for secretarial work.

M.K. and F.A. contributed equally to this work.

Correspondence should be addressed to Dr. Merab Kokaia, Section of Restorative Neurology, Wallenberg Neuroscience Center, University Hospital, S-221 85 Lund, Sweden.

Copyright (ㄷ) 1998 Society for Neuroscience $\quad 0270-6474 / 98 / 188730-10 \$ 05.00 / 0$ implying that the impaired short-term plasticity does not result from a developmental alteration. No changes of overall presynaptic release probability, measured by the progressive block of NMDA receptor-mediated synaptic currents by MK-801, or desensitization of AMPA receptors were detected. Because NT-3 expression is reduced after focal seizures, impaired short-term facilitation may represent a protective response that limits the propagation of epileptiform activity from the entorhinal cortex to the hippocampus.

Key words: neurotrophin-3; synaptic plasticity; dentate gyrus; hippocampal slices; whole-cell patch-clamp; knock-out mice

Whether endogenous NT-3 can influence synaptic transmission is not known. Compared with both its high-affinity receptor TrkC and the other neurotrophins, the NT-3 gene exhibits a specific and much more restricted pattern of expression. High levels of NT-3 mRNA are detected only in dentate granule cells and in pyramidal neurons of CA2 and the most medial part of the CA1 area (Ernfors et al., 1990; Maisonpierre et al., 1990b). Various insults to the brain, e.g., seizure activity, cerebral ischemia, hypoglycemic coma and traumatic injury (Lindvall et al., 1994), as well as induction of LTP (Castrén et al., 1993), trigger rapid, transient increases of NGF and BDNF mRNA levels but a decrease of NT-3 mRNA expression in dentate granule cells. Although some data are available on the effects of acute exposure of NT-3 to synapses in the CA1 region (Kang and Schuman, 1995), no studies have so far aimed at elucidating the role of endogenous NT-3 for transmission at synapses involving NT-3-producing neurons, such as dentate granule cells.

In the present study, we have explored the role of endogenous NT-3 for synaptic transmission, primarily at lateral perforant path (LPP)-dentate granule cell synapses using hippocampal slices from adult, heterozygous (+/-) NT-3 knock-out mice. As proposed for NGF and BDNF (Blöchl and Thoenen, 1996; Goodman et al., 1996), NT-3 can probably be released from the dendrites of dentate granule cells and interact with TrkC receptors localized on the afferent entorhinal cortical neurons and/or on the granule cells themselves (Merlio et al., 1992). The NT$3+/-$ mice show a $30 \%$ reduction of basal NT-3 mRNA levels in dentate granule cells (Elmér et al., 1997) and should be particularly useful for clarifying the functional consequences of the reduced NT-3 gene expression induced by various stimuli. We demonstrate that paired-pulse facilitation (PPF) and synaptic responses to brief, high-frequency afferent stimulation are reduced at LPP-dentate granule cell synapses of NT-3+/- mice. 
The deficit in PPF can be reversed by exogenous NT-3 through a mechanism requiring de novo protein synthesis.

\section{MATERIALS AND METHODS}

NT-3 knock-out mice. The NT-3+/- and NT-3+/+ mice were obtained from our breeding colony originating from heterozygous mutant mice purchased from Jackson Laboratories (Bar Harbor, Maine). Homozygous NT-3 ( $-/-)$ knock-out mice die within a few days after birth and therefore only heterozygotes $(+/-)$ were used. The NT-3+/- mice gained weight at the same rate, reached the same size as their littermates, and were normal in terms of fertility, gross behavior, and survival. All mice were genotyped, as described previously (Ernfors et al., 1994), at the age of 3-4 weeks. Experiments were performed on 4- to 8-weekold mice.

Slice preparation. The mice were anesthetized with Halothane and decapitated, and the brains were removed. The hippocampi were dissected in ice-cold artificial CSF (aCSF), and transverse hippocampal slices $(400-450 \mu \mathrm{m})$ were cut on a vibroslice (Campden Instruments). Slices were stored at room temperature, either submerged or in an interface chamber containing aCSF consisting of (in $\mathrm{mM}$ ): $119 \mathrm{NaCl}, 2.5$ $\mathrm{KCl}, 1.3 \mathrm{MgSO}_{4}, 2.5 \mathrm{CaCl}_{2}, 26.2 \mathrm{NaHO}_{3}, 1 \mathrm{NaH}_{2} \mathrm{PO}_{4}$, and 11 glucose, gassed with $95 \% \mathrm{O}_{2}$ and $5 \% \mathrm{CO}_{2}$. For the "rescue" experiments, the slices were incubated for 8-10 hr submerged in a chamber with aCSF to which either NT-3 (100 ng/ml) or cytochrome C450 (100 ng/ml) had been added. Cytochrome $\mathrm{C} 450$ was boiled before application. For protein synthesis inhibition experiments, slices were incubated as above but cycloheximide (CHM) $(40 \mu \mathrm{M})$ was added $30 \mathrm{~min}$ before NT-3.

Electrophysiology. Slices were transferred into the recording chamber where they were submerged in aCSF with the same composition as above except for the addition of $100 \mu \mathrm{M}$ picrotoxin to block $\mathrm{GABA}_{\mathrm{A}}$ receptors. When experiments were performed in the CA3 area, both $\mathrm{Ca}^{2+}$ and $\mathrm{Mg}^{2+}$ concentrations in the aCSF were $4 \mathrm{~mm}$. The LPP, Schaffer collaterals, and mossy fibers were stimulated with isolated bipolar stainless steel electrodes (constant voltage pulses, $20-100 \mu \mathrm{sec}$ ) at $0.067 \mathrm{~Hz}$. The LPP was identified as follows. Stimulation of the outer third of the stratum moleculare evoked EPSPs that reversed in polarity when the recording electrode was moved from the outer third to the middle third of the stratum moleculare (McNaughton, 1980; Hanse and Gustafsson, 1992a,b). The EPSP induced by a second pulse of two successive stimulations (50 msec interval) showed clear facilitation as compared with the first one (McNaughton, 1980; Colino and Malenka, 1993). The relation between the magnitude of the presynaptic fiber volley and field EPSP was analyzed. This relation was similar in NT-3+/+ and NT-3+/mice, suggesting that there were no alterations in basal synaptic transmission (see Fig. 1A). To discriminate between mossy fiber-CA3 and associational/commissural fiber-CA3 synapses, the presynaptic metabotropic glutamate receptor group 2-selective agonist $\left(2 \mathrm{~S}, 1^{\prime} 5,2^{\prime} \mathrm{S}\right)-2$ (carboxycyclopropyl)glycine (L-CCGI) $(10 \mu \mathrm{M})$ was added to the perfusion solution. Addition of L-CCGI blocked responses in mossy fiber-CA3 synapses but not those in associational/commissural-CA3 synapses (data not shown) (Kamiya et al., 1996; Castillo et al., 1997). The attenuation of the evoked EPSPs caused by L-CCGI was the same in NT-3+/+ and NT-3+/- mice, respectively (data not shown), indicating that the functionality of the mossy fibers was not altered in $+/-$ animals.

LTP was induced by tetanization of the LPP afferent inputs to dentate granule cells (10 stimuli, constant voltage pulses, $200 \mu \mathrm{sec}$, in two consecutive trains, $100 \mathrm{~Hz}$, with $20 \mathrm{sec}$ intertrain interval). Post-tetanic potentiation (PTP) was evoked by a single train of 100 pulses, $100 \mathrm{~Hz}$, in the presence of $50 \mu \mathrm{M} \mathrm{D}(-)$-2-amino-5-phosphonopentanoic acid (DAP5) in aCSF. The temperature of the recording chamber was kept at $21-23^{\circ} \mathrm{C}$.

Extracellular field EPSPs were recorded via a glass pipette containing $3 \mathrm{M} \mathrm{NaCl}(0.5-1 \mathrm{M} \Omega)$. Field potentials were amplified and filtered at 1 $\mathrm{kHz}$ and sampled at $10 \mathrm{kHz}$ with an EPC-9 patch-clamp amplifier (HEKA Electronics, Lambrecht, Germany), and stored on a Power Macintosh computer for off-line analysis. The initial slope and/or peak amplitude of the field EPSP was measured over a period of 1-2 msec.

Whole-cell recording pipettes (4-6 M $\Omega$ ) were filled with cesium gluconate (97.5 mM), CsCl (17.5 mM), HEPES (10 mM), BAPTA (10 mM), $\mathrm{NaCl}(8 \mathrm{~mm}), \operatorname{MgATP}(2 \mathrm{~mm}), \mathrm{GTP}$ (0.3 mm), and QX-314 Br (5 mM), pH 7.2, osmolarity 295 mOsm. Membrane currents were amplified and filtered at $2.9 \mathrm{kHz}$ and sampled at $10 \mathrm{kHz}$ with an EPC-9 patch-clamp amplifier. The series resistance was continuously monitored by delivering a voltage step command at the end of each trace recorded. The holding potential was $-70 \mathrm{mV}$ for recording AMPA receptor-mediated EPSCs and +40 or $+50 \mathrm{mV}$ for recording the NMDA receptor-mediated EPSCs. Junctional potentials were not corrected for. There was no significant difference in input resistance of the recorded cells between NT-3+/ - and NT-3+/+ mice $(640.2 \pm 89.5$ and $670.2 \pm 96.9 \mathrm{M} \Omega$, respectively), implying that the recorded cells were of the same developmental maturity (Liu et al., 1996). The EPSC amplitudes were measured over 1-2 msec for the AMPA and 7-10 msec for the NMDA component, coinciding with the peak of the EPSC time course.

PPF was calculated as the percentage increase of the initial slope of the second EPSP or amplitude of the second EPSC compared with that of the first [(EPSP2 - EPSP1)/EPSP1 $\times 100 \%]$. The synaptic response of the dentate granule cells during high-frequency stimulation (HFS) (10 pulses, $40 \mathrm{~Hz}$ ) in LPP was calculated as the integral of the total evoked synaptic currents $(0-300 \mathrm{msec})$ normalized to that of the first evoked synaptic current $(0-25 \mathrm{msec})$.

MK-801 $(80 \mu \mathrm{M})$ was applied by bath perfusion, with stimulation interrupted for 5-10 min. We confirmed that MK-801 had reached a stable concentration by the time stimulation was resumed, by verifying that the amplitude-normalized decay time course of the first few EPSCs was similar to that of the EPSCs recorded later in the course of the application of the drug. To estimate the rate of decay of the NMDA receptor-mediated EPSCs in the presence of MK-801, a single exponential time constant with a zero asymptote was fitted to all the EPSCs recorded in the presence of the blocker (Marquardt-Levenburg algorithm) (Kullmann et al., 1996).

Data analysis. Data acquisition was controlled by PULSE software (HEKA Electronics). Analyses and illustrations were made with PULSE and IGOR software (WaveMetrics, Lake Oswego, OR). Statistical analysis of the data were performed using Student's unpaired $t$ test or ANOVA with Bonferroni-Dunn post hoc test. Significance was set at $p<$ 0.05 . Data are expressed as mean \pm SEM. Unless explicitly stated, $n$ is number of animals.

Drugs. Drugs were purchased from ICN Biomedicals (Aurora, OH), except QX-314 Br (Alomone Laboratories, Israel) and NBQX, MK-801, cycloheximide, aniracetam, D-AP5 and L-CCGI (Tocris Cookson, Buckinghamshire, UK). Recombinant human NT-3 was kindly provided by Regeneron Pharmaceuticals.

\section{RESULTS}

\section{Pharmacological properties of AMPA and NMDA receptors at LPP-dentate granule cell synapses are not altered in NT-3+/- mice}

We first investigated the properties of excitatory transmission at LPP-dentate granule cell synapses by testing the functionality of AMPA and NMDA receptors. The $\mathrm{GABA}_{\mathrm{A}}$ receptor antagonist picrotoxin was used to block fast inhibitory synaptic transmission. Whole-cell patch-clamp recordings with cells clamped at $-70 \mathrm{mV}$ showed that the selective AMPA receptor antagonist NBQX blocked excitatory synaptic transmission to the same extent in the $\mathrm{NT}-3+/-$ and NT-3+/ + mice (to $5.8 \pm 1.8$ and $5.9 \pm 1.2 \%$ of control, respectively) (Fig. $1 B$ ). When cells were clamped at +40 or $+50 \mathrm{mV}$ in the presence of NBQX, the blockade of excitatory transmission caused by the selective NMDA receptor antagonist MK-801 did not differ between the NT-3+/ - and NT-3+/+ mice (to $3.3 \pm 1.0$ and $1.9 \pm 3.9 \%$ of control, respectively) (Fig. 1C). These results suggest that the pharmacological properties of AMPA and NMDA receptors were similar in NT-3 $+/-$ and $\mathrm{NT}-3+/+$ mice.

\section{Paired-pulse facilitation and the synaptic responses evoked by a brief, high-frequency train of stimuli are reduced at LPP-dentate granule cell synapses in NT-3+/- mice}

To further characterize excitatory synaptic transmission in LPPdentate granule cell synapses, we measured PPF and PTP. Paired-pulse facilitation and PTP are two forms of short-lasting synaptic potentiation believed to be attributable mainly to alterations of presynaptic calcium homeostasis (Zucker, 1989). When measured with an interstimulus interval (ISI) of $50 \mathrm{msec}$, we 

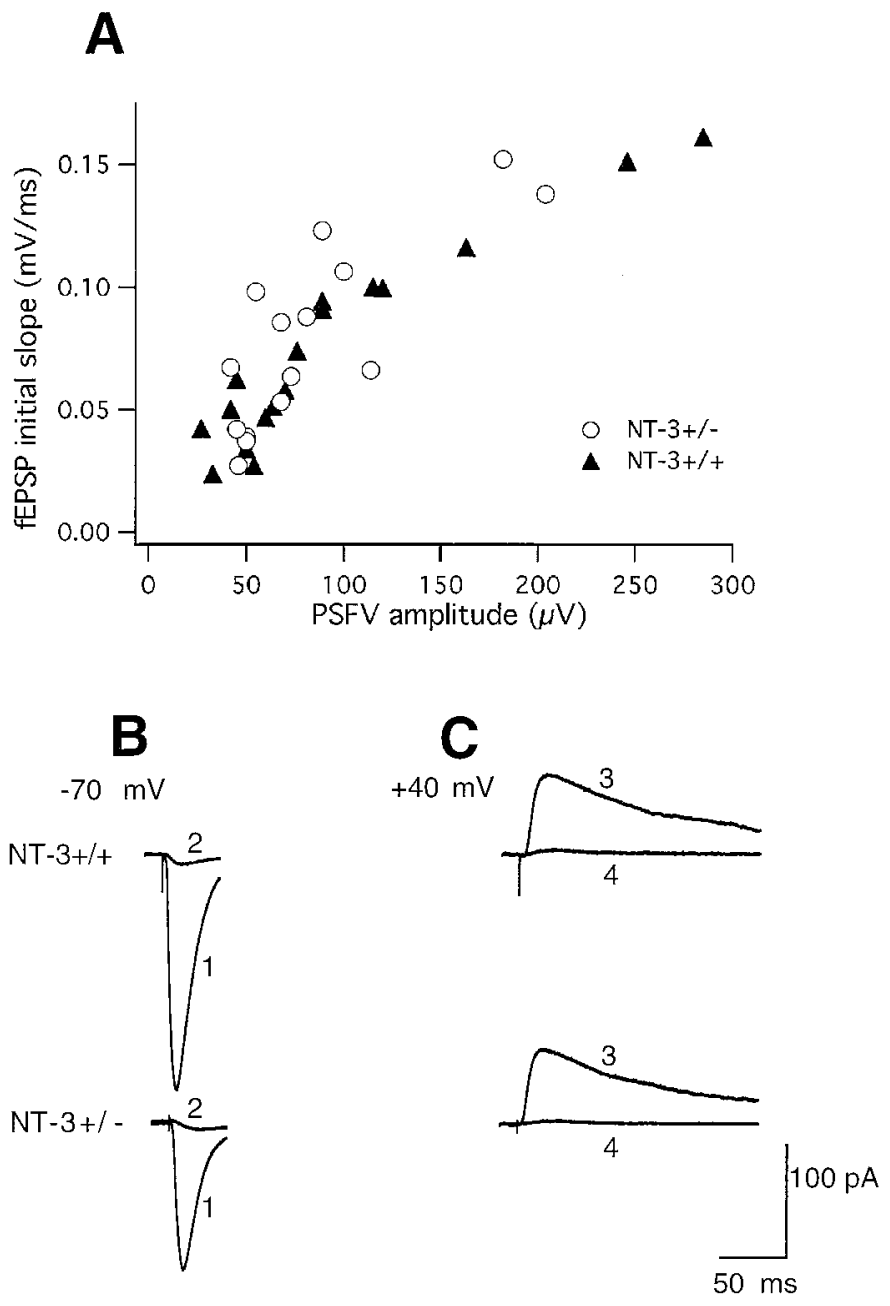

Figure 1. Basal properties of LPP-dentate granule cell synapses are not altered in NT-3+/- mice. $A$, Relation between the amplitude of the presynaptic fiber volley (PSFV) and the initial slope of field EPSP. Values are taken from individual experiments and are indicated by open circles (for NT-3+/-) and filled triangles (for NT-3+/+). B, Averaged EPSCs (10 traces) recorded in a dentate granule cell from a NT-3+/+ (top) or NT-3+/- (bottom) mouse at $-70 \mathrm{mV}$ before (trace 1) and after (trace 2) application of $5 \mu \mathrm{M}$ NBQX. $C$, Averaged EPSCs (10 traces) recorded in the same dentate granule cells at $+40 \mathrm{mV}$ with $\mathrm{NBQX}(5 \mu \mathrm{M})$ in the perfusion solution before (trace 3) and after (trace 4) application of $80 \mu \mathrm{M}$ MK-801.

found reduced PPF of EPSCs in NT-3+/- mice as compared with those in NT-3+/+ animals (Fig. $2 A$ ). On average, the PPF was $39.3 \pm 9.5 \%$ in NT-3+/+ and only $14.6 \pm 7.1 \%$ in NT-3+/mice (Fig. 2B). These experiments were performed with $10 \mathrm{~mm}$ BAPTA in the recording pipette, which makes it less likely that the observed difference in PPF was caused by altered postsynaptic buffering of calcium (Wang and Kelly, 1996).

In previous studies on BDNF knock-out mice, there has been a disagreement about whether PPF in Schaffer collateral-CA1 synapses is altered (Korte et al., 1995; Patterson et al., 1996). Part of this disagreement might be attributable to the fact that the investigators used different ISIs when eliciting PPF. We therefore studied PPF using several ISIs ranging from 25 to $200 \mathrm{msec}$. In these experiments, PPF was measured with field recordings. As illustrated in Figure $2 C$, there was a marked impairment of PPF in NT-3+/ - mice at short ISIs $(25,50$, and $100 \mathrm{msec})$, whereas no significant difference between the strains were observed at longer ISIs (200 msec).

We studied PTP induced by tetanic stimulation (100 pulses, 100 $\mathrm{Hz}$ ) at LPP-dentate granule cell synapses using field recordings. In contrast to PPF, no difference in PTP was found between NT-3+/+ and NT-3+/- mice (peak EPSP increase of $361 \pm 44 \%$ and $361 \pm 25 \%$, respectively, both decaying back to prestimulation values within 6-7 min after the tetanus; $n=5$ in each group).

We also analyzed short-term, activity-dependent plasticity by evoking synaptic responses through a short period of afferent HFS $(40 \mathrm{~Hz}$ ). Figure $2 D$ shows the synaptic responses resulting from such HFS stimulation of LPP fibers recorded with the whole-cell patch-clamp technique in dentate granule cells. The integrated synaptic response evoked by a brief HFS (normalized to that of the first response; see Materials and Methods) in slices from NT-3+/- mice was found to be, on average, $61.5 \%$ of that recorded in slices from NT-3+/+ animals (Fig. 2E). Furthermore, when comparing the initial slope of the synaptic response induced by the fourth pulse with that induced by the first one (cf. Figurov et al., 1996), the NT-3+/- mice exhibited a pronounced decay (to $51.1 \% \pm 9.9 \% ; n=10$ ), which was not observed to the same extent in NT-3+/+ mice (to $97.0 \% \pm 19.0 \% ; n=7, p<$ $0.05)$. These results indicate that not only the synaptic facilitation but also the synaptic depression seen with HFS (Zucker, 1989) is altered in NT-3+/- mice.

\section{Paired-pulse facilitation is not impaired at Schaffer collateral-CA1 or mossy fiber-CA3 synapses in NT-3+/- mice}

During embryonic and early postnatal development, NT-3 is transiently expressed at relatively high levels in several brain areas (Maisonpierre et al., 1990a; Friedman et al., 1991; Ernfors et al., 1992). To explore the possibility that the deficit in PPF in LPP-dentate granule cell synapses of the NT-3+/- mice was caused by a more general dysfunction, possibly resulting from a lack of NT-3 during development, we investigated PPF also in Schaffer collateral-CA1 synapses. These synapses are located in an area of the hippocampus where the expression of NT-3 mRNA and presumably also of protein in the adult brain are very low (Ernfors et al., 1990; Maisonpierre et al., 1990b). Figure $3 A$ shows the averaged results of field recordings of PPF in Schaffer collateral-CA1 synapses from NT-3+/+ and NT-3+/- mice. No significant differences in PPF were found at any ISI.

In the next step, we extended these experiments to mossy fiber-CA3 synapses. Recent studies (Altar et al., 1997; Smith et al., 1997) have suggested that BDNF, synthesized in dentate granule cells, is transported anterogradely in the mossy fiber system to the CA3 region. Therefore, although NT-3 mRNA expression is very low in CA3 neurons (Ernfors et al., 1990; Maisonpierre et al., 1990b), it cannot be excluded that NT-3 is transported anterogradely from the soma of the dentate granule cells and acts at mossy fiber-CA3 synapses. However, using various ISIs, we did not detect any differences between NT-3+/and NT-3+/+ mice in PPF at these synapses (Fig. 3B).

\section{Impairment of PPF in NT-3+/- mice can be reversed by exposure to exogenous NT-3}

To provide further evidence against a developmental deficit as the underlying cause for the impairment of PPF in the NT-3+/mice, hippocampal slices from these animals were incubated in a solution containing recombinant NT-3. We found that recombinant NT-3 but not the control protein cytochrome C450 [a protein of similar molecular weight and properties as NT-3 (Yan 
A
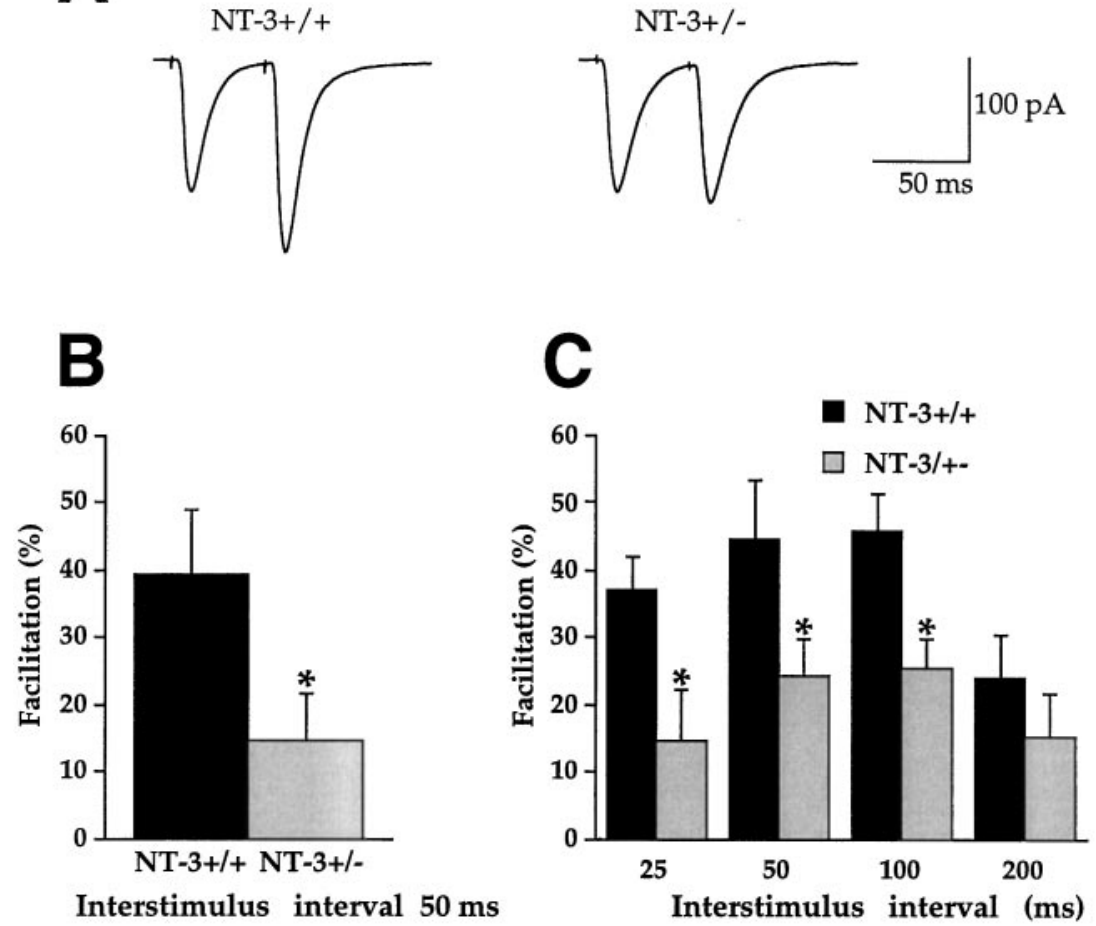

D
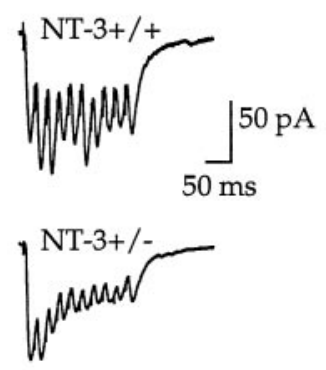

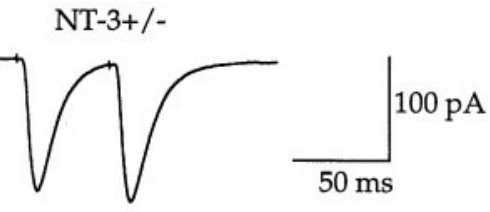

Interstimulus interval (ms)
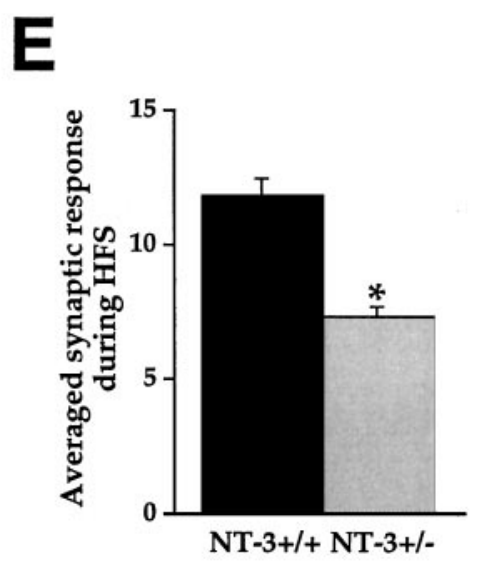

Figure 2. PPF and synaptic responses induced by short high-frequency afferent stimulation are reduced in LPPdentate granule cell synapses of NT-3+/- mice. $A$, Averaged EPSCs (10 traces) recorded in a dentate granule cell from an NT-3+/+ and an NT-3+/- mouse, respectively, in response to two stimuli delivered with an ISI of 50 msec. $B$, Averaged PPF of EPSCs ( \pm SEM) in dentate granule cells from NT-3 $+/+(n=6$ cells $)$ and NT- $3+/-$ ( $n=11$ cells) mice at $50 \mathrm{msec}$ ISI. $C$, Averaged PPF $( \pm$ SEM) at different ISIs, as measured using field recordings, in NT-3 $+/+(n=5)$ and NT-3+/- $(n=8)$ mice, respectively. $D$, Averaged EPSCs (10 traces) in dentate granule cells from NT-3+/+ and NT- $3+/-$ mice during short high-frequency stimulation of LPP afferents (10 pulses, $40 \mathrm{~Hz}$ ). $E$, Averaged synaptic responses of dentate granule cells from NT-3+/+ $(n=7$ cells $)$ and NT-3 $+/-$ $(n=10$ cells $)$ mice during HFS $(10$ pulses, $40 \mathrm{~Hz})$ of LPP afferents. The synaptic response was calculated as the integral of the total evoked synaptic currents $(0-300$ $\mathrm{msec})$ normalized to that of the first evoked synaptic current $(0-25 \mathrm{msec})$. et al., 1992)], could "rescue" the deficit of PPF seen in NT-3+/animals (Fig. 4A). There was a significantly higher PPF in NT3-treated slices as compared with slices exposed to cytochrome $\mathrm{C} 450$ at both $25 \mathrm{msec}(34.0 \pm 3.2 \%$ and $10.9 \pm 2.6 \%$, respectively) and $50 \mathrm{msec}$ ISI $(48.9 \pm 4.9$ and $29.7 \pm 4.8 \%$, respectively; $n=9$ for each group), whereas the addition of NT-3 had no effect on PPF with longer ISIs. In agreement with the findings of Patterson et al. (1996), using recombinant BDNF, we found that the slices had to be incubated with NT-3 for 8-10 hr for a significant rescue effect to be observed. This long incubation time might reflect slow penetration of recombinant NT-3 into the slices, as described previously for BDNF (Patterson et al., 1996), or requirement for protein synthesis (Kang and Schuman, 1996). To show that the rescue effect occurred only in LPP-dentate granule cell synapses with low endogenous NT-3 levels, we also incubated slices from NT-3+/+ mice with either NT-3 or cytochrome C450. No significant differences in PPF were observed in these slices [31.0 \pm $7.3 \%$ and $30.0 \pm 5.2 \%$ at $25 \mathrm{msec}$ ISI, and $45.7 \pm 7.3 \%$ and $39.0 \pm$
$3.3 \%$ at 50 msec ISI in NT-3-added (11 slices; three animals) and control (nine slices; three animals) slices, respectively]. Taken together, our results suggest that the deficit in PPF in NT-3+/mice can be reversed by exposure to recombinant NT-3 and that the rescue effect is specific for these mice.

\section{Reversal of the deficit in PPF by exogenous NT-3 requires de novo protein synthesis}

To test the hypothesis that the reversal of the PPF deficit by exogenous NT-3 could be mediated by de novo synthesis of a putative peptide or protein, we administered recombinant NT-3 to hippocampal slices from NT-3+/- mice treated with the protein synthesis inhibitor $\mathrm{CHM}$. Cycloheximide was added to the incubation solution $30 \mathrm{~min}$ before the application of recombinant NT-3, as described previously (Kang and Schuman, 1996). In the cytochrome C450-treated control slices from NT-3+/mice, the PPF showed the expected deficit at various ISIs (Fig. $4 B$ ), which closely resembled that observed in the previous ex- 

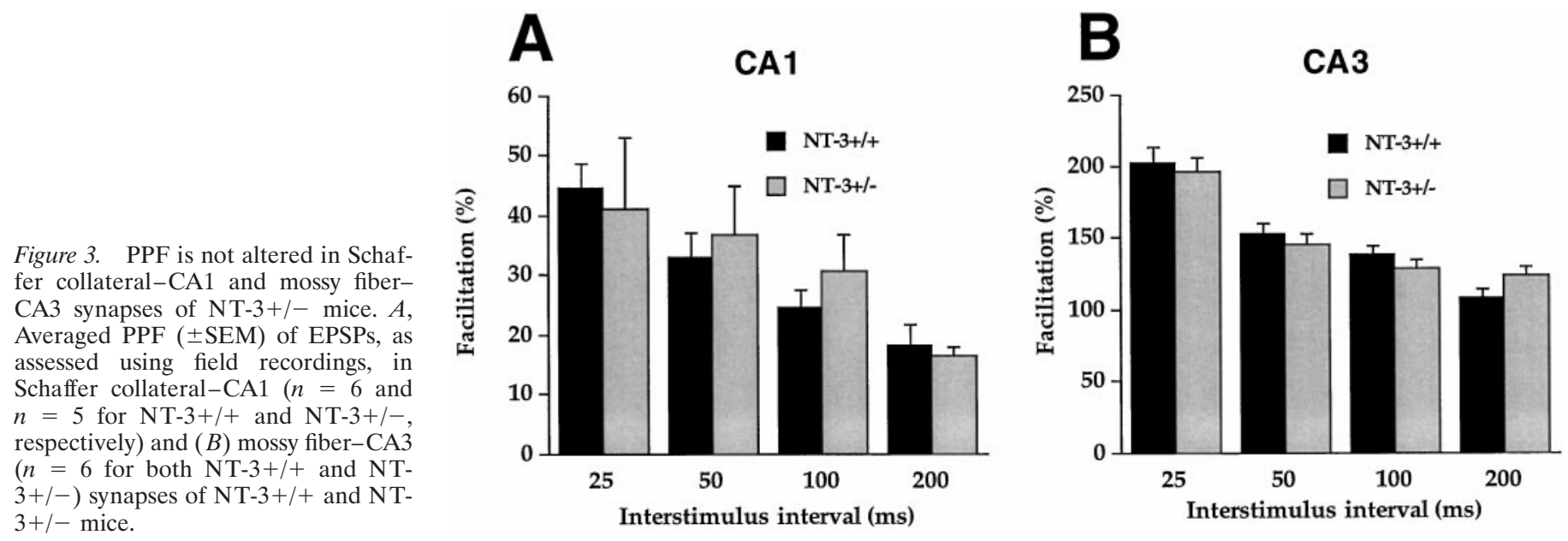

Figure 4. The impaired PPF in NT$3+/-$ mice can be rescued by application of recombinant NT-3 with a mechanism requiring protein synthesis. $A$, Averaged PPF ( \pm SEM) measured using field recordings at different ISIs in slices from NT-3+/ - mice incubated with either recombinant NT-3 or cytochrome C450 (Cyt.C) ( $n=9$ for each group). $B$, Same experimental paradigm as in $A$, but $\mathrm{CHM}$ was added to the incubation solution $30 \mathrm{~min}$ before application of NT-3. In addition, a separate set of slices was exposed to CHM alone $(n=6$ for each group).
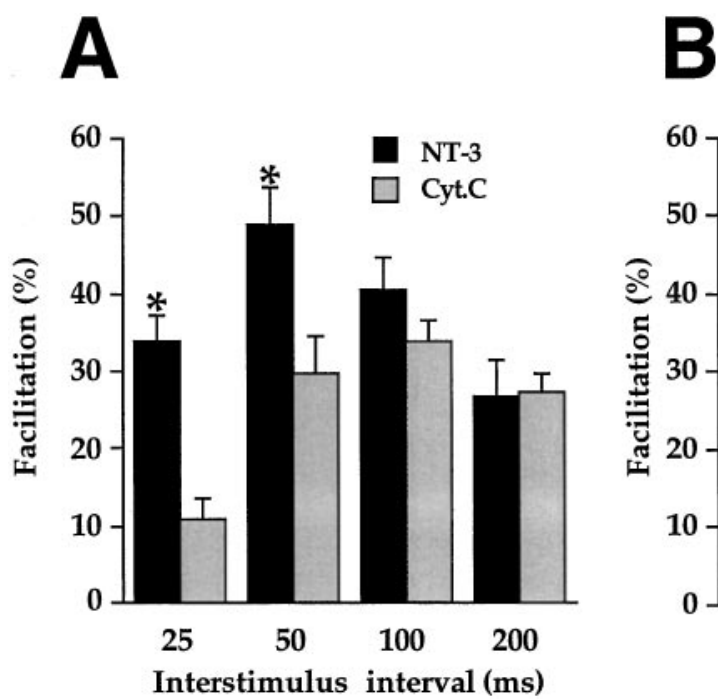

periment (Fig. 4A). Administration of $\mathrm{CHM}$ to slices without subsequent exposure to NT-3 did not influence PPF (Fig. 4B). The rescue effect on the deficit in PPF, observed after incubation of slices from NT-3+/- mice with recombinant NT-3 for 8-10 hr (Fig. 4B), was completely prevented by previous addition of CHM. This finding indicates that the rescue effect is dependent on de novo protein synthesis.

\section{Presynaptic release probability is not altered in NT-3+/- mice}

Previous experiments have shown that changes in overall presynaptic release probability can influence PPF (Manabe et al., 1993; Asztely et al., 1996; Debanne et al., 1996). We investigated whether the synaptic mechanism underlying the deficit in PPF in $\mathrm{NT}-3+/-$ mice could be an alteration of presynaptic release probability. The progressive block of NMDA receptor-mediated synaptic currents by MK-801 can be used for the estimation of overall release probability (Hessler et al., 1993; Rosenmund et al., 1993). Because increased glutamate release should cause NMDA receptor channels to open more frequently, the rate at which MK-801 attenuates successive NMDA receptor-mediated responses is increased with higher release probability. Figure 5 summarizes the results of the MK-801 blocking experiments. A comparison of first degree exponential fits of the MK-801induced EPSC blockade curves did not reveal any significant difference between NT-3+/+ and NT-3+/ - mice in the overall release probability from LPP terminals $(\tau=17.8 \pm 3.1$ and $16.8 \pm 2.2$, respectively; $p=0.8$ ).

\section{Desensitization mechanisms of AMPA receptors are not altered in NT-3+/- mice}

The altered PPF in NT-3+/- mice might also be attributable to a postsynaptic mechanism. For example, an allosteric modulation of AMPA receptors affecting the binding kinetics and/or desensitization could cause the impairment of PPF seen with short ISIs. To explore this possibility we performed experiments using aniracetam, an allosteric modulator of the AMPA receptor, presumably interfering with the desensitization mechanism (Isaacson and Nicoll, 1991; Tang et al., 1991). Averaged data from whole-cell patch-clamp and field recordings demonstrate that the effect of aniracetam on the kinetics of the EPSCs and EPSPs, respectively, did not differ between NT-3+/+ and NT-3+/mice. The decay time constant in the presence of aniracetam for the EPSP/EPSC was found to be $150.1 \pm 4.3 \%$ and $154.7 \pm 1.8 \%$ of control, respectively ( $n=8$ and $n=11$ ). This finding makes it less likely that the changes of PPF at short ISIs and the depression seen with HFS in NT-3+/- mice are attributable to altered desensitization of the AMPA receptors. 

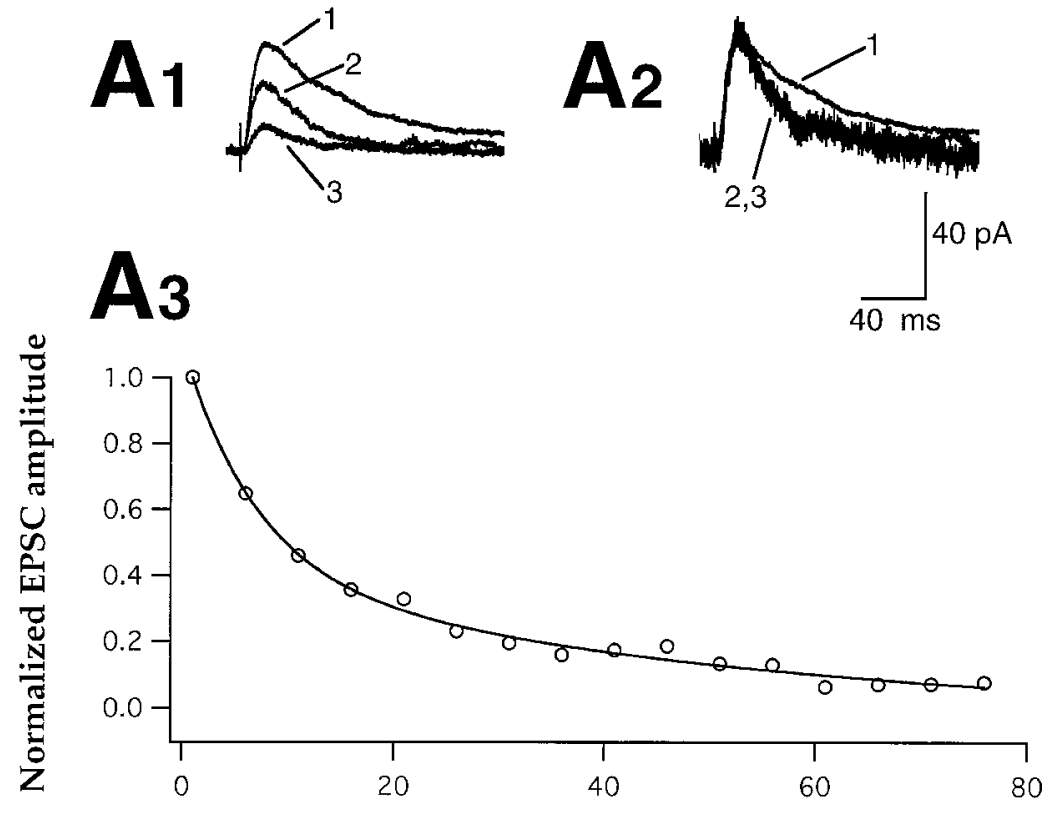

Number of stimulation

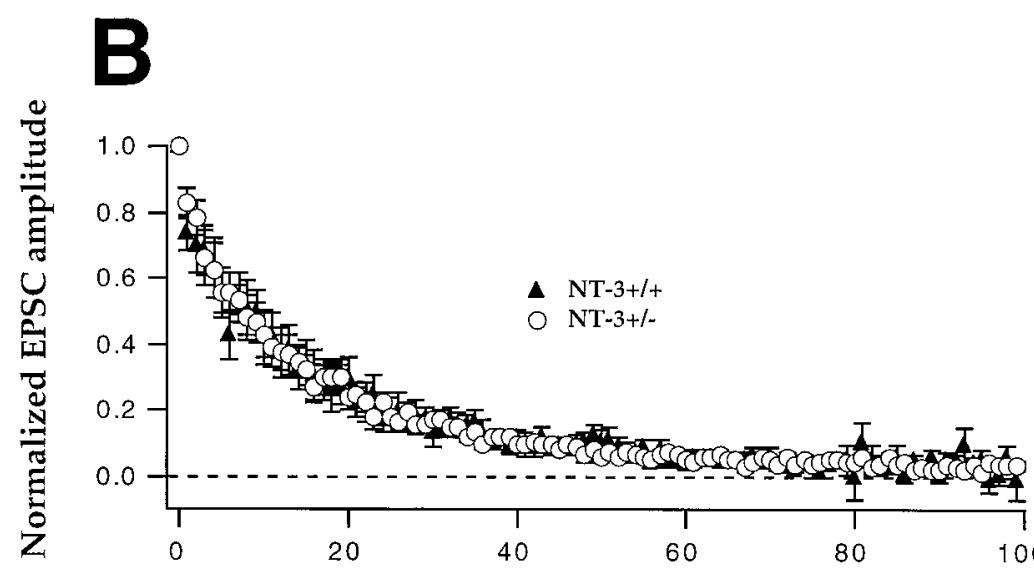

Number of stimulation
Figure 5. Overall release probability is not altered in NT$3+1-$ mice. A1, Averaged (5 responses) NMDA receptormediated responses recorded in the absence (trace 1) and in the presence of MK-801 $(80 \mu \mathrm{M})$ (trace 2, average of responses 1-5; trace 3, average of responses 21-25). The dentate granule cell was clamped at $+50 \mathrm{mV}$ with $5 \mu \mathrm{M}$ NBQX added to the perfusion medium. $A 2$, The same traces as in $A 1$ normalized to the peak value of trace 1 , showing a faster decay of the evoked EPSCs in the presence of MK-801. As can be seen, the accelerated decay of the evoked EPSCs is similar in traces 2 and 3, indicating that blockade of NMDA receptors by MK- 801 was equally efficient throughout the whole experiment. A3, Mean amplitude of successive NMDA receptor-mediated EPSCs (same cell as in $A_{1}$, average of 5 responses) recorded in the presence of MK-801, normalized to the first response $(\bigcirc)$. The line represents a first degree exponential curve fit to the amplitude decay. $B$, Average of the mean amplitude decay of the successive NMDA receptormediated EPSCs recorded in the presence of MK-801 (normalized to the first response). The decay rate in cells from NT-3 $+/+$ mice $(\boldsymbol{\Delta} ; n=8$ cells $)$ was not different from that of NT-3 $+/-$ mice $(O ; n=9$ cells $)$.

\section{Long-term potentiation is not impaired at LPP-dentate granule cell synapses in NT-3+/- mice}

To investigate whether the NT-3+/- mice exhibited deficits not only in short- but also in long-lasting synaptic plasticity, we induced LTP (Bliss and Collingridge, 1993) in LPP-dentate granule cell synapses. Because the postsynaptic activity during the induction of LTP seems to be an important factor determining the magnitude and duration of LTP (Malenka, 1991; Hanse and Gustafsson, 1992b), we hypothesized that the LTP induced by a given train could be less stable in NT-3+/- mice. In agreement with this notion, application of TrkB-IgG has been shown to reduce the postsynaptic response to repetitive stimulation in the CA1 region of hippocampal slices and also the stability of LTP (Figurov et al., 1996), indicating that activation of TrkB by endogenous BDNF could influence the induction of LTP (but see Kang et al., 1997).

Figure 6 shows that the LTP induced in hippocampal slices from NT-3+/- mice (open circles) did not differ from that in slices from NT-3+/+ animals (filled triangles). These findings indicate that the expression of LTP is not impaired in NT-3+/- mice. Furthermore, the data suggest that the increased synaptic depression and therefore presumably reduced cumulative depolarization in these mice during high-frequency repetitive stimulation (with the parameters used here) does not affect the induction of LTP. Similar findings have been reported by Geppert et al. (1994) in Rab3A knock-out mice and by Rosahl et al. (1995) in synapsin I and II knock-out mice.

\section{DISCUSSION}

The major finding of this study is that PPF and synaptic responses to HFS are decreased in LPP-dentate granule cell synapses of mice heterozygous for a deletion of the NT-3 gene. Post-tetanic potentiation, another form of short-term synaptic plasticity, is not altered in these synapses of the mutant animals. The observed effects are not caused by changes in inhibitory synaptic transmission because the $\mathrm{GABA}_{\mathrm{A}}$ receptor antagonist picrotoxin was used throughout the experiments. Furthermore, there was no evidence of a deficit in the functionality of NMDA or AMPA receptors.

Paired-pulse facilitation is traditionally accounted for by the presynaptic residual calcium hypothesis of Katz and Miledi 


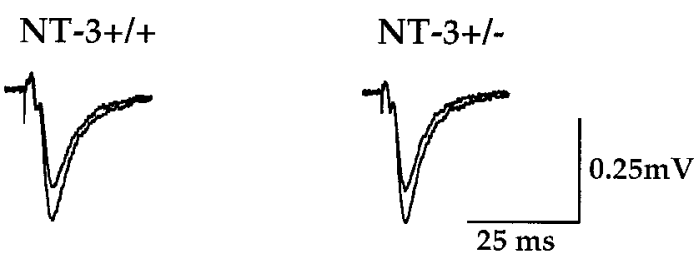

Figure 6. NT-3+/- mice can express LTP in LPP-dentate granule cell synapses. Averaged EPSP slopes from NT-3+/+ $(\mathbf{\Delta} ; n=$ 12) and NT-3+/- $(\bigcirc ; n=9)$ mice, respectively, plotted against time. At $t=0$, the LPP afferents were tetanized ( 2 trains, 10 impulses, $100 \mathrm{~Hz}, 20 \mathrm{sec}$ apart). The averaged $( \pm$ SEM) changes of EPSP slope are plotted in percentage of the mean EPSP slope value obtained during $10 \mathrm{~min}$ before the stimulation. Insets demonstrate EPSP traces (average of 20) before and after (at 50 min) the tetanus in representative slices from NT-3+/+ and NT-3+/- mice.

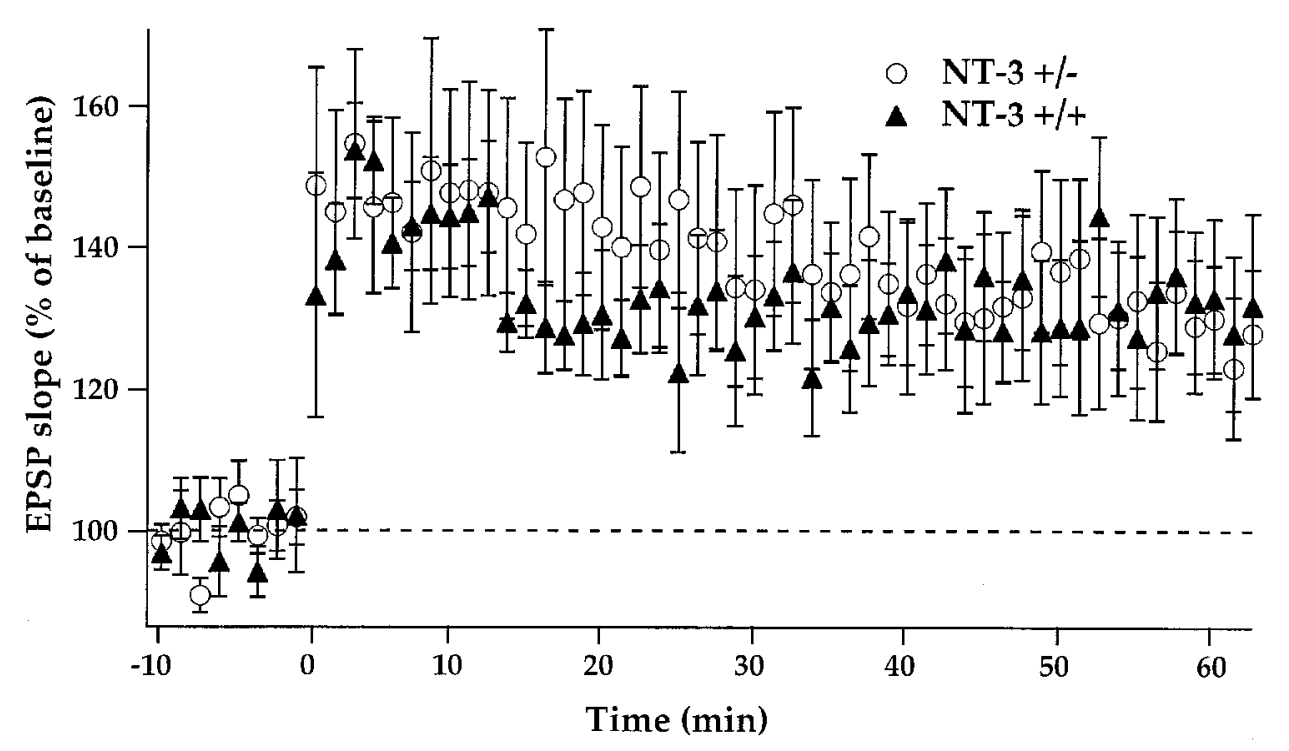

To account for the present findings we have to postulate that NT-3 affects part(s) of the presynaptic release machinery presumably independent of or not controlling the mechanisms altering overall $p_{\mathrm{r}}$. The observed decrease in PPF could then either be caused by decreased facilitation or increased depression of neurotransmitter release. Hypothetically, a change in the expression or phosphorylation/dephosphorylation of one or several of the proteins involved in vesicle fusion and release of neurotransmitter (Sudhof, 1995) might lead to the reduced PPF. In support of the latter hypothesis, NT-3 has been shown to increase the expression of several exocytosis-associated proteins in cultures of embryonic cortical neurons (Takei et al., 1997). Similar to our experiments, changes in PPF without alteration in MK-801 blocking rate has been reported in neural cultures obtained from mice deficient in the vesicle-associated GTP-binding protein Rab3A (Geppert et al., 1997). The authors argued that this dissociation could be explained by Rab3A acting at a late stage in synaptic vesicle fusion. Whether NT-3 acts via this pathway remains to be determined. In this context it is interesting to note that PPF but not PTP was altered in NT-3+/- mice. The mechanisms of PPF are believed to operate in close proximity to the transmitter release sites, whereas PTP is induced and maintained at locations throughout the core of the presynaptic terminals (Zucker, 1989; Fisher et al., 1997). Thus, the finding of altered PPF but not PTP in NT-3+/- mice might suggest that NT-3 is affecting events taking place at the site of synaptic vesicle fusion.

A possible explanation for the impairment of PPF in NT-3+/mice could be a developmental abnormality in these animals, resulting in medial perforant path (MPP) forming synapses not only with the middle third but also with the outer third of the dendritic tree of the granule cells. It has been shown that PPF is much lower in MPP as compared with LPP synapses. In fact, there is paired-pulse depression (PPD) in MPP-dentate gran- receptor-mediated responses to the same degree in NT-3+1- and $\mathrm{NT}-3+/+$ mice does not support this hypothesis. 
ule cell synapses (McNaughton, 1980; Colino and Malenka, 1993). If there was such a developmental deficit in NT-3+/mice, stimulation in the outer third of the dendritic tree could have recruited MPP fibers, with a low PPF or even PPD. However, our finding that MK-801 attenuated successive NMDA receptor-mediated responses to the same extent in NT-3+/- and NT-3+/+ mice argues against this scenario (Min et al., 1998). The observation that the impairment of PPF is rescued by exogenous NT-3 application in slices from NT-3 $+/-$ mice but that PPF is not altered by NT-3 exposure in NT-3+/+ animals also makes this interpretation unlikely.

Our data indicate that the deficit in PPF is caused by acute effects on synaptic function attributable to lower availability of NT-3. First, incubation of slices from NT-3+/- mice with recombinant NT-3 reversed the deficit in PPF at LPP-dentate granule cell synapses. This is similar to the rescue effect observed by recombinant BDNF on the deficit in LTP at Schaffer collateralCA1 synapses in BDNF knock-out mice (Patterson et al., 1996). These findings provide further evidence against a developmental defect as the underlying cause. Second, the impairment of PPF was detected specifically at those synapses at which NT-3, based on the high gene expression in dentate granule cells, most likely is released at high levels. In contrast, no deficit was detected at Schaffer collateral-CA1 and mossy fiber-CA3 synapses where NT-3 release is probably very low.

Kang and Schuman (1995) have reported a decrease in PPF at Schaffer collateral-CA1 synapses in hippocampal slices after exogenous bath application of either BDNF or NT-3. In contrast, we observed a reduction of PPF at LPP-dentate granule cell synapses in NT-3+/- mice, and Patterson et al. (1996) found a decrease of PPF at Schaffer collateral-CA1 synapses in $\mathrm{BDNF}+/-$ and $\mathrm{BDNF}-/-$ mice. One possible explanation for this discrepancy might be that in the present experiments picrotoxin was used to block $\mathrm{GABA}_{\mathrm{A}}$ receptor-mediated inhibition. Application of exogenous NT-3 or BDNF has been described to attenuate GABAergic inhibition (Kim et al., 1994; Rutherford et al., 1997). Such disinhibition by NT-3 therefore might mask actual changes in PPF of excitatory synaptic transmission. Alternatively, in the study of Kang and Schuman (1995), the relatively high concentration of exogenously applied NT-3 may have activated not only TrkC but also the BDNF receptor TrkB, leading to the observed changes in PPF. The fact that exposure to recombinant NT-3 had no effect on PPF in slices from NT-3 $+/+$ mice in our study implies that under basal conditions endogenous NT-3 at LPP-dentate granule cell synapses reaches above a certain threshold level for normal short-term plasticity.

The site of action of NT-3 to regulate PPF could be localized either on the presynaptic entorhinal cortical neuron or the postsynaptic dentate granule cell, both of which express TrkC (Merlio et al., 1992). Kang and Schuman (1996) have proposed that the enhancement of excitatory transmission at Schaffer collateral-CA1 synapses exerted by BDNF and NT-3 is dependent on local protein synthesis, probably in the dendrites of CA1 pyramidal neurons. Similarly, we found that inhibition of protein synthesis with CHM prevented the rescue effect on PPF exerted by recombinant NT-3 in the NT-3+/- mice. This suggests that NT-3, released from dendrites of dentate granule cells, interacts with TrkC receptors on the same or neighboring granule cells to influence the synthesis of proteins regulating excitatory synaptic transmission. Because PPF is regarded as a presynaptic phenomenon and we found no evidence of a change in postsynaptic responsiveness, it is conceivable that these newly synthesized proteins regulate neurotransmitter release by communicating with the presynaptic terminal (Kang and Schuman, 1996).

What could be the functional consequences of the reduced NT-3 mRNA and presumably also protein level in dentate granule cells induced by various insults (Lindvall et al., 1994)? It has been shown in the kindling epilepsy model that decreased NT-3 mRNA expression is triggered already by one single seizure episode lasting 60-70 sec or more (Bengzon et al., 1993), and that NT-3 mRNA is reduced for several days after recurring seizures (Elmér et al., 1996). The present data indicate that reduced NT-3 levels lead to a faster attenuation of consecutive synaptic responses to a short HFS at LPP-dentate granule cell synapses. It is tempting to speculate that this faster attenuation also can occur during repetitive, synchronized seizure discharges in vivo. Based on a number of experimental observations (Stringer and Pan, 1998), it has been suggested that the dentate gyrus acts as a gate for the passage of epileptiform activity from the entorhinal cortex into the hippocampus proper. A long-lasting decrease of NT-3 expression in dentate granule cells therefore could act to dampen the recruitment of the hippocampal excitatory neural circuitry in epileptiform activity and thereby suppress the generalization of epileptic seizures. In agreement with this hypothesis, NT-3+/mice exhibit a retardation of the development of generalized but not focal epileptic seizures evoked by daily kindling stimulations in the amygdala (Elmér et al., 1997). However, once the epileptic syndrome had been fully expressed, there was no difference between NT-3+/- and NT-3+/+ mice in seizure generalization. LTP has been implicated as a possible mechanism involved in the development of kindling epilepsy (Cain, 1989; McEachern and Shaw, 1996). In accordance with the fact that NT-3+/- mice can exhibit fully kindled seizures, we found here that these animals can also express LTP in LPP-granule cell synapses. It remains to be elucidated whether possibly compromised induction of LTP could be revealed in NT-3+/- mice by using a weaker induction protocol.

The decrease of NT-3 expression in dentate granule cells after seizures, however, is only part of a cascade of changes triggered by the same stimuli. These changes include more rapid and transient increases of the synthesis of NGF and BDNF as well as of TrkB and TrkC receptors, which are probably all co-expressed in the same dentate granule cells (Kokaia et al., 1993; Miranda et al., 1993). However, current knowledge of neurotrophin action on synaptic transmission is based solely on studies of the effects of exposure to or knock-out of one single neurotrophin. It seems highly warranted to pursue these studies by exploring the functional consequences of simultaneous manipulations of the levels of several neurotrophins and their receptors, similar to what has been observed after insults to the adult brain.

\section{REFERENCES}

Akaneya Y, Tsumoto T, Kinoshita S, Hatanaka H (1997) Brain-derived neurotrophic factor enhances long-term potentiation in rat visual cortex. J Neurosci 17:6707-6716.

Altar CA, Cai N, Bliven T, Juhasz M, Conner JM, Acheson AL, Lindsay RM, Wiegand SJ (1997) Anterograde transport of brain-derived neurotrophic factor and its role in the brain. Nature 389:856-860.

Asztely F, Xiao MY, Gustafsson B (1996) Long-term potentiation and paired-pulse facilitation in the hippocampal CA1 region. NeuroReport 7:1609-1612.

Bengzon J, Kokaia Z, Ernfors P, Kokaia M, Leanza G, Nilsson OG, Persson H, Lindvall O (1993) Regulation of neurotrophin and trkA, trkB and trkC tyrosine kinase receptor messenger RNA expression in kindling. Neuroscience 53:433-446.

Bliss TV, Collingridge GL (1993) A synaptic model of memory: longterm potentiation in the hippocampus. Nature 361:31-39. 
Blöchl A, Thoenen H (1996) Localization of cellular storage compartments and sites of constitutive and activity-dependent release of nerve growth factor (NGF) in primary cultures of hippocampal neurons. Mol Cell Neurosci 7:173-190.

Bonhoeffer T (1996) Neurotrophins and activity-dependent development of the neocortex. Curr Opin Neurobiol 6:119-126.

Cain DP (1989) Long-term potentiation and kindling: how similar are the mechanisms? Trends Neurosci 12:6-10.

Castillo PE, Janz R, Sudhof TC, Tzounopoulos T, Malenka RC, Nicoll RA (1997) Rab3A is essential for mossy fibre long-term potentiation in the hippocampus. Nature 388:590-593.

Castrén E, Pitkanen M, Sirvio J, Parsadanian A, Lindholm D, Thoenen H, Riekkinen PJ (1993) The induction of LTP increases BDNF and NGF mRNA but decreases NT-3 mRNA in the dentate gyrus. Neuroreport 4:895-898.

Colino A, Malenka RC (1993) Mechanisms underlying induction of long-term potentiation in rat medial and lateral perforant paths in vitro. J Neurophysiol 69:1150-1159.

Debanne D, Guerineau NC, Gahwiler BH, Thompson SM (1996) Paired-pulse facilitation and depression at unitary synapses in rat hippocampus: quantal fluctuation affects subsequent release. J Physiol (Lond) 491:163-176.

Elmér E, Kokaia M, Ernfors P, Ferencz I, Kokaia Z, Lindvall O (1997) Suppressed kindling epileptogenesis and perturbed BDNF and TrkB gene regulation in NT-3 mutant mice. Exp Neurol 145:93-103.

Elmér E, Kokaia M, Kokaia Z, Ferencz I, Lindvall O (1996) Delayed kindling development after rapidly recurring seizures: relation to mossy fiber sprouting and neurotrophin, GAP-43 and dynorphin gene expression. Brain Res 712:19-34.

Ernfors P, Ibanez CF, Ebendal T, Olson L, Persson H (1990) Molecular cloning and neurotrophic activities of a protein with structural similarities to nerve growth factor: developmental and topographical expression in the brain. Proc Natl Acad Sci USA 87:5454-5458.

Ernfors P, Merlio LP, Persson H (1992) Cells expressing mRNA for neurotrophins and their receptors during embryonic rat development. Eur J Neurosci 4:1140-1158.

Ernfors P, Lee KF, Kucera J, Jaenisch R (1994) Lack of neurotrophin-3 leads to deficiencies in the peripheral nervous system and loss of limb proprioceptive afferents. Cell 77:503-512.

Figurov A, Pozzo Miller LD, Olafsson P, Wang T, Lu B (1996) Regulation of synaptic responses to high-frequency stimulation and LTP by neurotrophins in the hippocampus. Nature 381:706-709.

Fisher SA, Fisher TM, Carew TJ (1997) Multiple overlapping processes underlying short-term synaptic enhancement. Trends Neurosci 20: 170-177.

Foster TC, McNaughton BL (1991) Long-term enhancement of CA1 synaptic transmission is due to increased quantal size, not quantal content. Hippocampus 1:79-91.

Friedman WJ, Ernfors P, Persson H (1991) Transient and persistent expression of NT-3/HDNF mRNA in the rat brain during postnatal development. J Neurosci 11:1577-1584.

Geppert M, Bolshakov VY, Siegelbaum SA, Takei K, De Camilli P, Hammer RE, Sudhof TC (1994) The role of Rab3A in neurotransmitter release. Nature 369:493-497.

Geppert M, Goda Y, Stevens CF, Sudhof TC (1997) The small GTPbinding protein Rab3A regulates a late step in synaptic vesicle fusion. Nature 387:810-814.

Goodman LJ, Valverde J, Lim F, Geschwind MD, Federoff HJ, Geller AI, Hefti F (1996) Regulated release and polarized localization of brain-derived neurotrophic factor in hippocampal neurons. Mol Cell Neurosci 7:222-238.

Hanse E, Gustafsson B (1992a) Long-term potentiation and field EPSPs in the lateral and medial perforant paths in the dentate gyrus in vitro: a comparison. Eur J Neurosci 4:1191-1201.

Hanse E, Gustafsson B (1992b) Postsynaptic, but not presynaptic, activity controls the early time course of long-term potentiation in the dentate gyrus. J Neurosci 12:3226-3240.

Hessler NA, Shirke AM, Malinow R (1993) The probability of transmitter release at a mammalian central synapse. Nature 366:569-572.

Hjelmstad GO, Nicoll RA, Malenka RC (1997) Synaptic refractory period provides a measure of probability of release in the hippocampus. Neuron 19:1309-1318.

Isaacson JS, Nicoll RA (1991) Aniracetam reduces glutamate receptor desensitization and slows the decay of fast excitatory synaptic currents in the hippocampus. Proc Natl Acad Sci USA 88:10936-10940.
Kamiya H, Shinozaki H, Yamamoto C (1996) Activation of metabotropic glutamate receptor type $2 / 3$ suppresses transmission at rat hippocampal mossy fibre synapses. J Physiol (Lond) 493:447-455.

Kang H, Schuman EM (1995) Long-lasting neurotrophin-induced enhancement of synaptic transmission in the adult hippocampus. Science 267:1658-1662.

Kang H, Schuman EM (1996) A requirement for local protein synthesis in neurotrophin-induced hippocampal synaptic plasticity. Science 273:1402-1406.

Kang H, Welcher AA, Shelton D, Schuman EM (1997) Neurotrophins and time: different roles for TrkB signaling in hippocampal long-term potentiation. Neuron 19:653-664.

Katz B, Miledi R (1968) The role of calcium in neuromuscular facilitation. J Physiol (Lond) 195:481-492.

Kim HG, Wang T, Olafsson P, Lu B (1994) Neurotrophin 3 potentiates neuronal activity and inhibits gamma-aminobutyratergic synaptic transmission in cortical neurons. Proc Natl Acad Sci USA 91:12341-12345.

Kokaia Z, Bengzon J, Metsis M, Kokaia M, Persson H, Lindvall O (1993) Coexpression of neurotrophins and their receptors in neurons of the central nervous system. Proc Natl Acad Sci USA 90:6711-6715.

Korte M, Carroll P, Wolf E, Brem G, Thoenen H, Bonhoeffer T (1995) Hippocampal long-term potentiation is impaired in mice lacking brain-derived neurotrophic factor. Proc Natl Acad Sci USA 92:8856-8860

Korte M, Griesbeck O, Gravel C, Carroll P, Staiger V, Thoenen H, Bonhoeffer T (1996) Virus-mediated gene transfer into hippocampal CA1 region restores long-term potentiation in brain-derived neurotrophic factor mutant mice. Proc Natl Acad Sci USA 93:12547-12552.

Kullmann DM, Erdemli G, Asztely F (1996) LTP of AMPA and NMDA receptor-mediated signals: evidence for presynaptic expression and extrasynaptic glutamate spill-over. Neuron 17:461-474.

Lessmann V, Gottmann K, Heumann R (1994) BDNF and NT-4/5 enhance glutamatergic synaptic transmission in cultured hippocampal neurones. Neuroreport 6:21-25.

Levine ES, Dreyfus CF, Black IB, Plummer MR (1995) Brain-derived neurotrophic factor rapidly enhances synaptic transmission in hippocampal neurons via postsynaptic tyrosine kinase receptors. Proc Natl Acad Sci USA 92:8074-8077.

Lewin GR, Barde YA (1996) Physiology of the neurotrophins. Annu Rev Neurosci 19:289-317.

Lindsay RM, Wiegand SJ, Altar CA, DiStefano PS (1994) Neurotrophic factors: from molecule to man. Trends Neurosci 17:182-190.

Lindvall O, Kokaia Z, Bengzon J, Elmer E, Kokaia M (1994) Neurotrophins and brain insults. Trends Neurosci 17:490-496.

Liu YB, Lio PA, Pasternak JF, Trommer BL (1996) Developmental changes in membrane properties and postsynaptic currents of granule cells in rat dentate gyrus. J Neurophysiol 76:1074-1088.

Lu B, Figurov A (1997) Role of neurotrophins in synapse development and plasticity. Rev Neurosci 8:1-12.

Maisonpierre PC, Belluscio L, Friedman B, Alderson RF, Wiegand SJ, Furth ME, Lindsay RM, Yancopoulos GD (1990a) NT-3, BDNF, and NGF in the developing rat nervous system: parallel as well as reciprocal patterns of expression. Neuron 5:501-509.

Maisonpierre PC, Belluscio L, Squinto S, Ip NY, Furth ME, Lindsay RM, Yancopoulos GD (1990b) Neurotrophin-3: a neurotrophic factor related to NGF and BDNF. Science 247:1446-1451.

Malenka RC (1991) Postsynaptic factors control the duration of synaptic enhancement in area CA1 of the hippocampus. Neuron 6:53-60.

Manabe T, Wyllie DJ, Perkel DJ, Nicoll RA (1993) Modulation of synaptic transmission and long-term potentiation: effects on paired pulse facilitation and EPSC variance in the CA1 region of the hippocampus. J Neurophysiol 70:1451-1459.

McEachern JC, Shaw CA (1996) An alternative to the LTP orthodoxy: a plasticity-pathology continuum model. Brain Res, Brain Res Rev 22:51-92.

McNaughton BL (1980) Evidence for two physiologically distinct perforant pathways to the fascia dentata. Brain Res 199:1-19.

Merlio JP, Ernfors P, Jaber M, Persson H (1992) Molecular cloning of rat trkC and distribution of cells expressing messenger RNAs for members of the trk family in the rat central nervous system. Neuroscience 51:513-532.

Min M-Y, Asztely F, Kokaia M, Kullmann DM (1998) Long-term potentiation and dual-component quantal signalling in the dentate gyrus. Proc Nat Acad Sci USA 95:4702-4707. 
Miranda RC, Sohrabji F, Toran Allerand CD (1993) Neuronal colocalization of mRNAs for neurotrophins and their receptors in the developing central nervous system suggests a potential for autocrine interactions. Proc Natl Acad Sci USA 90:6439-6443.

Murthy VN, Sejnowski TJ, Stevens CF (1997) Heterogeneous release properties of visualized individual hippocampal synapses. Neuron 18:599-612.

Patterson SL, Abel T, Deuel TA, Martin KC, Rose JC, Kandel ER (1996) Recombinant BDNF rescues deficits in basal synaptic transmission and hippocampal LTP in BDNF knockout mice. Neuron 16:1137-1145.

Rosahl TW, Spillane D, Missler M, Herz J, Selig DK, Wolff JR, Hammer RE, Malenka RC, Sudhof TC (1995) Essential functions of synapsins I and II in synaptic vesicle regulation. Nature 375:488-493.

Rosenmund C, Clements JD, Westbrook GL (1993) Nonuniform probability of glutamate release at a hippocampal synapse. Science 262:754-757.

Rutherford LC, DeWan A, Lauer HM, Turrigiano GG (1997) Brainderived neurotrophic factor mediates the activity-dependent regulation of inhibition in neocortical cultures. J Neurosci 17:4527-4535.

Schulz PE, Cook EP, Johnston D (1994) Changes in paired-pulse facilitation suggest presynaptic involvement in long-term potentiation. J Neurosci 14:5325-5337.

Schulz PE, Cook EP, Johnston D (1995) Using paired-pulse facilitation to probe the mechanisms for long-term potentiation (LTP). J Physiol (Paris) 89:3-9.

Smith MA, Zhang LX, Lyons WE, Mamounas LA (1997) Anterograde transport of endogenous brain-derived neurotrophic factor in hippocampal mossy fibers. Neuroreport 8:1829-1834.

Stringer JL, Pan E (1998) Role of the dentate gyrus in the spread of seizures within the hippocampal-parahippocampal circuit. In Corcoran, E. M. and Moshé, S. L. (eds), Kindling 5. Plenum Press: New York, pp.89-99.

Sudhof TC (1995) The synaptic vesicle cycle: a cascade of proteinprotein interactions. Nature 375:645-653.

Takei N, Sasaoka K, Inoue K, Takahashi M, Endo Y, Hatanaka H (1997) Brain-derived neurotrophic factor increases the stimulation-evoked release of glutamate and the levels of exocytosis-associated proteins in cultured cortical neurons from embryonic rats. J Neurochem $68: 370-375$.

Tang CM, Shi QY, Katchman A, Lynch G (1991) Modulation of the time course of fast EPSCs and glutamate channel kinetics by aniracetam. Science 254:288-290.

Thoenen H (1995) Neurotrophins and neuronal plasticity. Science 270:593-598.

Wang JH, Kelly PT (1996) Regulation of synaptic facilitation by postsynaptic $\mathrm{Ca} 2+/ \mathrm{CaM}$ pathways in hippocampal CA1 neurons. J Neurophysiol 76:276-286.

Yan Q, Elliott J, Snider WD (1992) Brain-derived neurotrophic factor rescues spinal motor neurons from axotomy-induced cell death. Nature 360:753-755.

Zucker RS (1989) Short-term synaptic plasticity. Annu Rev Neurosci 12:13-31. 